\title{
ROLE OF BEHAVIORAL BIASES IN REAL ESTATE PRICES IN PAKISTAN
}

\author{
M Asad Saleem Malik \\ Management Sciences Department \\ National University of Modern Language, Islamabad \\ e-mail:asadmalik@live.com

\section{Muhammad Zafar} \\ Management Sciences Department \\ National University of Modern Language, Islamabad \\ e-mail: zafar498872@gmail.com
}

\section{Saif Ullah}

Management Sciences Department

SZABIST, Karachi

e-mail: saifullah_142@yahoo.com

\author{
Atta Ullah \\ School of Management \\ Huazhong University of Science and Technology, Wuhan-China \\ e-mail: 1201822097@hust.edu.cn
}

\begin{abstract}
The study aims to explore the effect of behavioral biases on financial decision making in the real estate sector of Pakistan. The data of a sample of 244 real estate investors are collected through a survey carried out using different sources. The findings of the study show the relationship of different biases, including overconfidence, herding effect, gambler's fallacy, and regret aversion on prices of real estate. Real estate prices are more affected by overconfidence and gambler's fallacy than herding effect and regrets aversion bias in Pakistan. The findings furthermore reveal that these biases do not depend on gender, education, and demographics. It is recommended to carefully consider the market factors while making decisions in real estate, as the prices do not always show the real value of the property.
\end{abstract}

Key words: financial decision making, overconfidence bias, herding effect bias, gambler's fallacy bias, regret aversion bias, real estate sector.

JEL Classification: P34, D03, G11, L85, L83.

Citation: Malik, M.A.S., Zafar, M., Ullah, S. \& Ullah, A. (2021). Role of behavioral biases in real estate prices in Pakistan. Real Estate Management and Valuation, 29(1), 41-53.

DOI: https://doi.org/10.2478/remav-2021-0005

\section{Introduction}

There is no valid law and authority for the regulation of real estate prices, which has led to a monopoly of a few giant investors in Pakistan. The value of real estate depends on the law of demand and supply. The prices of real estate inflate due to overconfident investors and their herd behavior; this artificial price level is then maintained, and arbitragers are the intermediaries who come to play 
their role to bring prices to an equilibrium level (Constantinescu, 2010; Ndiritu, 2015). Experiments demonstrated both positive and negative inflation shocks that have an asymmetrical impact on price rise with negative shock, not loading so readily to price settlement as a positive shock.

Wealth creation is dependent on the decisions made by the investors; this either increases wealth if decisions are wise and in line with the movement in markets, or deteriorate it if decisions are not made correctly, and this can harm (Burtch, 2011). According to behavioral finance, the behavior of human being depends largely on many factors and may even lead to them making different decisions in alike situations (Babajide \& Adetiloye, 2012; Khan, 2020). Behavioral biases may be divided into two types, one depends on an emotional timeline, which may start with hope and end in fear. The second type of behavioral bias depends on the information heard in specific areas, where individual decides based on what other people are doing and follows the same trend.

The current study will help investors make rational decisions and be a contribution to research on behavioral bias, seeing as now various types of emotions have a different impact on investors' behaviors and their decisions, affecting them both positively or negatively as reported by (Lopes, 2016). When an investor decides in a state of fear, he experiences restlessness and this results in regret if it is not in line with the outcomes so expected when making a decision, which is not a rational state of decision making. On the other hand, when the investor makes any decision based on the market situation with hope that adds satisfaction, and this later results in pride, this occurs mostly under the phenomenon of favorable market conditions. So fear is doomed towards regret, whereas hope towards the upside of the market outcomes.

This study intends to address the research question of what will be the effect of behavioral bias on real estate prices? The study of behavioral bias in real estate is a contribution to literature in the Pakistani context. This study seeks to dispel the fear of prevailing high real estate prices and the role of heuristic biases on price changes. Investors in real estate seem confused when investing due to price volatility. The researchers have much interest in behavioral finance, and they want to provide investors with a scale that may help them in their decision making in the neglected area of real estate. Investors tend to and need to focus on factors that help them to make rational decisions, which maximize their return at lower risk and cost without involving emotional feelings in financial decision making (Brabazon, 2001; Shah, et al., 2018). A recent study by Atif Sattar, Toseef and Fahad Sattar, (2020) suggested that behavioral biases have a significant effect on investment decisions and it is therefore noteworthy to explore these dimensions.

This research paper is an effort to help investors in rational decision making after considering the behavior and effect of these biases and proper understanding of how these biases affect real estate prices. It helps the investor to have foresight into his opportunities that will ultimately maximize his wealth. They should also look outside the box, seeing as how there may be other excellent opportunities that will lower his risk as well as increasing his return if the sector is switched when making financial decisions and upon preparing the right portfolio combination. Individual investors need to analyze the investment factors carefully, using reasonable business knowledge and with an understanding of the effects of heuristic biases into behaviors before making an investment decision. It is also essential for real estate investors to look into each new opportunity according to market conditions, as healthy development never matches the past, and sticking to the available past information and recent experience exposes one to heuristic biases, which ultimately misleads the investor and may lead to losing excellent opportunities which may have arisen if he had followed rational decision making. The investor should take advantage of the latest development situation and consider all the significant variables instead of just focusing on a single area of expertise. This may also cause hazardous decision-making and may result in higher risk and the loss of good opportunities. Investors need to evaluate the market very carefully before they make investment decisions. Before entering into investments, there is a need for investors to possess sufficient knowledge regarding the market so that they are able to make wise decisions. Investors need to gather much information about the market to make sound investment decisions.

\section{Literature review}

The fact that behavioral biases have an impact on the individuals' decision making was confirmed by Luong and Ha (2011) in Vietnam, who recommended further research directions to confirm these findings in different sectors and countries to assess their demographic application or expose their implications based on new findings. A study by Choka (2014) on the influence of investors' sentiments 
on real estate investments determined that their sentiments significantly influence their decisionmaking on real estate. In addition to this, another study reported that investors oftentimes make their financial decisions due to overexcitement and overreaction based on a rise and fall in prices of real estate commodities. Investment decisions are significantly influenced by overthinking, overconfidence, hindsight, cognitive bias and herding (Chapra, et al., 2018). There is therefore a need to carry out research into the influence of behavior biases on individual investment decisions (Aigbovo \& Ilaboya, 2019). The investigations undertaken by the current study are therefore vital for increasing our understanding of this untapped area.

\subsection{Real estate prices}

The real estate industry may be defined as the buying and selling of land, building, its improvement, rental prices, the economic rent of land and building, and other improvements, including the construction industry. In the current context, real estate prices are not regulated by any authority. Real estate investments and prices are good measures for reflecting expected real estate demand and serve as good predictors of economic growth (Stilwell, 2011; Obeng-Odoom, 2015). The "real estate" market and industry are considered as land and improvements, their selling and rental prices, the economic rent of land and returns on buildings and other improvements, and the construction industry. Although real estate values are influenced by the supply and demand for properties in a given location and the replacement cost of developing new properties, the income approach is the most common valuation technique for investors. The income approach provided by appraisers of commercial properties and by underwriters and investors of real estate-backed investments is very similar to the discounted cash flow analysis conducted on equity and bond investments (Jennergren, 2011; Ndiritu, 2015).

Investors give more weight to where the possibility of outcome is certain, rather than where there is a probability, tending to averse the later; this feature is known as the "certainty effect" (Kahneman \& Tversky, 1979; Mather, et al., 2012; Majewski, 2018). People's choices are affected by the framing phase; framing refers to the approach of an individual, that is how the same problem is viewed, weighted and handled by an individual, and how the decision-maker deals with it, as well as by how this influences decision making; framing may lead to rational or irrational decision making (Kahneman \& Tversky, 2013). It can therefore be concluded that people do not make an independent analysis of their available options; and are instead influenced by the options and choices available to them, so the decision making of investors affects the prices of real estate.

\subsection{Behavioral biases}

Heuristics biases, such as representativeness, gambler's fallacy, overconfidence, anchoring and availability, are common and easily observed in one's decision-making style. When the situation of uncertainty is complicated, decision making arises and heuristics aid quick decision making (Ritter, 2003). The decision-makers, based on their experience and using probability to predict the future based on little relevant information, decide by making the complex phenomenon into a simple and easy one, which favors their ideas and perceptions (Tversky \& Kahneman, 1974); Waweru, et al., 2008).

Representativeness is the similarity of an event to other events which have occurred or its population (DeBondt \& Thaler, 1994). Representative bias occurs when the decision-maker gives too much relevance of situations experienced in the near past to a given situation, and thus avoids its realistic judgment and analysis (Ritter, 2003). When a small sample is applied to a large population, in view of the law of small numbers, it tilts to gambler's fallacy (Rabin, 2002; Statman, 2009). In real estate, gambler's fallacy works when the investors make decisions inaccurately at reverse points. This may be the end of a good or bad period for investment returns prevailing in the current market, when the decision is made based on heuristic bias (Waweru, et al., 2008).

\subsubsection{Overconfidence}

Overconfidence can be defined as unmerited confidence in self's judgments and abilities. Odean (2008) described overconfidence as the belief that a trader's information is more precise than it actually is. This is equivalent to narrow confidence intervals in predictions. Daniel and Hirshleifer (2015) defined an overconfident investor as one who overestimates the precision of his private information signal, but not of information signals publicly received by all. Overconfidence may be 
observed in various forms; for example self-attribution bias is when an individual takes credit for success, but discredits failures to bad luck (Ehrlinger, et al., 2016).

Hilton (2006) comments on the illusion of control, when people overestimate their own intellect and abilities. Unrealistic optimism is the expectation of success in the future as more favorable than in reality (Bracha \& Brown,2012). Feduzi and Runde (2014) argue confirmation bias to be behavior of individuals to favor and confirm information which is in line with their expectations and beliefs regarding the outcomes.

Malmendier and Tate (2005) discuss the better than average effect, which is connected with people thinking that they are better than others in their abilities, planning and fortune. Hence, individuals believe their abilities to be better than their peers. Calibration is defined as one's correction where they are wrong or misdirected. On the other hand, when individuals think they can never be wrong, they become prey of miscalibration and overconfidence.

The crux of all types of overconfidence is that overconfident people believe that their decisions shall prove that they were right, even though, in reality, the decisions taken may not be rational at all. They may suffer losses based on such decisions, and are not ready to accept this reality. It is not a rule of thumb that all rash decisions result in losses, as they may sometimes lead to gaining returns beyond their expectations and judgments (Odean, 2008). Overconfident people are less diverse, frequent traders and their volumes of trade are also high, which results in the liquidity of firms they invest in and keeps the market dynamic, despite the risk being higher. The claim that trading volumes can increase through overconfident behavior is supported by (Madaan \& Singh, 2019; Mushinada \& Veluri, 2018; Phan, et al., 2018; Khan, et al., 2017; Darrat, et al., 2007).

\subsubsection{Herding effect}

In financial terms and when it comes to decision-making, the herding effect means the trend of following the actions of others when it comes to buying and selling real estate. Experts consider the herd effect carefully as, in the market, most investors follow collective information instead of private sources, which may fundamentally deviate prices from real value, and thus the opportunity to earn or avoid losses may be impacted due to this behavior. Researchers value the herd effect, as this behavior impacts the theory of risk and return, thus having a significant effect on real estate and stock prices, as well as an impact on the asset pricing model theory (Tan, et al., 2008). Investors may prefer herd behavior over rational behavior when they are sure they can gain higher returns than expected under such market conditions.

In the perspective of behavior, herding can cause some emotional biases, including conformity, congruity, cognitive conflict, the home bias and gossip. Investors may prefer herding if they believe that it can help them to extract useful and reliable information. On the other hand, the performances of financial professionals, for example fund managers or financial analysts, are usually evaluated by a subjectively periodic assessment made on a relative basis and a comparison to their peers. In this case, herding can contribute to the evaluation of professional performance because those with low-ability may mimic the behavior of their high-ability peers in order to develop their professional reputation (Kallinterakis, et al., 2010). Herding behavior exists in and influences property investment decisions made by fund managers (Madaan \& Singh, 2019). A study by Filiz, Nahmer, Spiwoks and Bizer (2018) found non-optimal portfolio choices to be significantly influenced by herding behavior.

In the security market, herding investors base their investment decisions on the masses' decisions of buying or selling stocks. In contrast, informed and rational investors tend not to follow the flow of masses, which is what makes the market efficient. Herding, on the other hand, causes a state of an inefficient market, which is usually recognized by speculative bubbles. In general, herding investors act in the same way as prehistoric men, who had little knowledge and information about the surrounding environment and gathered in groups to support each other and get safety (Caparrelli, et al., 2004).

\subsubsection{Gambler's fallacy}

Kahneman and Tversky (2013) have commented on gambler's fallacy as a misconception of the law of probability. The main drawback of this bias is that investors who fall victim of it are likely to predict reversal in the prices of real estate and common stocks. This bias arises when an investor inappropriately predicts that prices will reverse and becomes controversial in thinking. Gambler's 
fallacy takes place when an investor conducts activities with expectations that errors in random distribution shall automatically rectify, and these are self-correcting. This bias may be exemplified; let us imagine a coin being tossed twenty times and heads turning up every time. An individual is asked to choose heads or tails for the 21st toss. The individual chooses tails in view that it is now a turn for tails, although this has nothing to do with previous occurrences; under such a condition, an individual is said to be the prey of gambler's fallacy (Montier, 2003).

In the Bombay stock exchange, the fact that expectations of investors capitalizing in stocks are influenced by gambler's fallacy leading to adverse effects of investment decision outcomes, was confirmed by (Asad, et al., 2018; Rakesh, 2014).

The belief that a small sample can resemble the parent population from which it is drawn is known as the "law of small numbers" (Rabin, 2002; Statman, 2009), which may lead to a gambler's fallacy (Barberis \&Thaler, 2003). More specifically, in the stock market, gambler's fallacy arises when people inaccurately predict reverse points, which are considered to be the end of good (or weak) market returns (Waweru, et al., 2008). Typical behavior of people subject to status quo bias is when they tend to select a suboptimal alternative simply because it had been chosen previously (Kempf \& Ruenzi, 2006).

\subsubsection{Regret aversion}

Regret aversion is a psychological error that arises out of an excessive focus on feelings of regret at having made a decision, which turned out to be poor, mainly because the outcomes of the alternative are visibly better for the investor. The root cause of this type of error is the tendency of individuals to hate admitting their mistakes. Because of suffering from this bias, investors may avoid taking decisive actions in fear that whatever decisions they make will be sub-optimal in hindsight. Regret is explained as an emotion felt when comparing the forgone choice with the given outcome by Razek (2011). Therefore, investors might avoid selling stocks that have moved downward just to avoid making a bad investment or because they are embarrassment by loss. One potential downside is that this could lead investors into holding onto a losing position for too long, because of an unwillingness to admit and rectify mistakes promptly. Another downside is that it can stop investors from making an entry into the market when there has been a downtrend which is showing signs of ending, signaling that this is an excellent time to buy.

The fear of regret often happens when individuals procrastinate when making decisions. Various psychological experimental studies suggest that regret influences decision-making under uncertainty. People who are regret averse tend to avoid distress arising out of two types of mistakes; errors of commission - which occur as a result of misguided action, where the investor reflects on this decision and rues the fact that he had made it, thus questioning his beliefs; errors of omission - which occur as a result of missing an opportunity which had existed (Pompian, 2006).

\subsection{Theoretical framework}

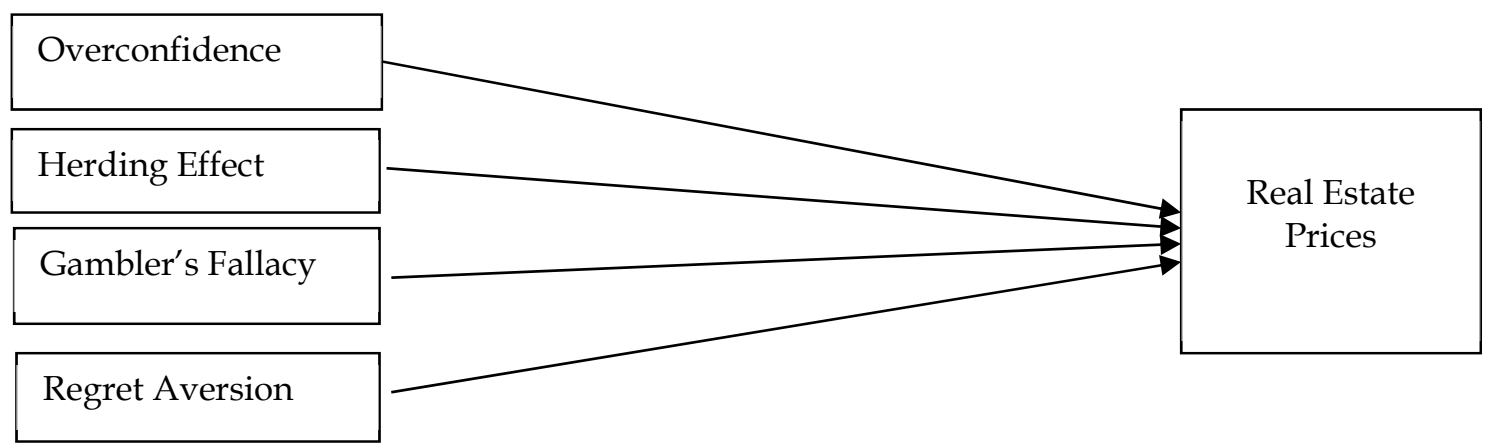

Fig. 1. Theoretical Framework. Source: own study.

\subsection{Research Hypotheses}

$\mathrm{H}_{1}$ : Overconfidence Bias plays a role in Real Estate Prices in Pakistan.

$\mathrm{H}_{2}$ : Herding Effect plays a role in Real Estate Prices in Pakistan.

$H_{3}$ : Gambler's Fallacy plays a role in Real Estate Prices in Pakistan. 


\section{$\mathrm{H}_{4}$ : Regret Aversion plays a role in Real Estate Prices in Pakistan.}

\section{Data and Methods}

\subsection{Participants and Procedure}

This study shall use a descriptive research design. The target population of the study comprises the real estate agents in Pakistan.

The following regression model is used:

$$
\mathrm{Y}=\mathrm{B}_{0}+\mathrm{B}_{1} \mathrm{X}_{1}+\mathrm{B}_{2} \mathrm{X}_{2}+\mathrm{B}_{3} \mathrm{X}_{3}+\mathrm{B}_{4} \mathrm{X}_{4}+\varepsilon
$$

\subsection{Instruments}

Five variables are used in this study, i.e., overconfidence bias, herding effect, gambler's fallacy, regret aversion and real estate prices. The source of the instruments used is Njenga and Kagiri (2018), with data collected using emails and online Google survey forms in order to save time and reduce costs during the period of November 2019 to March 2020.

Overconfidence Bias - Respondents were required to indicate the extent to which they agreed with various aspects of overconfidence bias and its influence on real estate market prices. Items were measured on a five-point Likert-Type scale ranging from 1 indicating "Strongly Disagree" to 5 indicating "Strongly Agree." An example of the items is "I believe that my skills and knowledge of the real estate market can help me to outperform the market" and "I am generally able to anticipate the end of a tremendous or weak market".

Herding Effect - Respondents were further required to indicate the extent to which they agreed with various aspects of the herding effect and its influence on real estate market prices. Items were measured on a five-point Likert-Type scale ranging from 1 indicating "Strongly Disagree" to 5 indicating "Strongly Agree." An example of an item is: "Thinking hard and for a long time about something gives me little satisfaction" and "Other investors' decisions on choosing real estate types have an impact on my investment decisions."

Gambler's Fallacy - Respondents were further required to indicate the extent to which they agreed with various aspects of gambler's fallacy and its influence on real estate market prices. Items were measured on a five-point Likert-Type scale ranging from 1 indicating "Strongly Disagree" to 5 indicating "Strongly Agree." Examples of the items include "I usually fix a target price for buying/selling in advance" and "I am averse to uncertainties."

Regret Aversion - Respondents were further required to indicate the extent to which they agreed to various aspects of regret aversion and its influence on real estate market prices. Items were measured on a five-point Likert-Type scale ranging from 1 indicating "Strongly Disagree" to 5 indicating "Strongly Agree." Examples of the items are "I have made an investment decision to buy or sell a real estate that I still regret having made" and "I avoid deciding in fear of failure the success of my investments."

Real Estate Market Prices - Respondents were finally asked to indicate the extent to which they agreed to various aspects of real estate market prices in Pakistan. Items were measured on a five-point Likert-Type scale ranging from 1 indicating "Strongly Disagree" to 5 indicating "Strongly Agree." Examples of the items are "Real estate prices are affordable in Pakistan" and "Real estate in Pakistan is cheap."

Other Variables - we employed age, gender, work experience, and the highest level of education as demographic variables. One-way ANOVA comparing real estate prices across different groups showed insignificant differences.

\subsection{Reliabilities of the Scales}

Thescale to measure overconfidence bias consists of 5 items. Cronbach's Alpha shows a value of alpha $(a=0.79)$, which is higher than the alpha value of 0.7 recommended as indicating reliability of the scale. This therefore shows that our scale is reliable to measure the selected variable. The scale for measuring Herding Effect consist of 5 items. Cronbach's Alpha test shows a value of alpha $(\alpha=0.87)$, which is higher than the alpha value 0.7 recommended for assessing the reliability of the scale. This shows that our scale is reliable for measuring the selected variable. The scale for measuring gambler's fallacy consists of 5 items. Cronbach's Alpha test revealed an alpha value of $(\alpha=0.82)$, which is higher than the alpha value of 0.7 recommended for assessing the reliability of the scale. This indicates that our 
scale is reliable for measuring the selected variable. The scale for measuring real estate market prices consists of 5 items. Cronbach's Alpha test shows a value of alpha $(\alpha=0.85)$, which is higher than the alpha value of 0.7 recommended for assessing the reliability of the scale. This shows that our scale is reliable when it comes to measuring the selected variable.

Reliabilities of the Scales $(\mathrm{N}=244)$

Table 1

\begin{tabular}{clcc}
\hline Sr. No & Variable & Cronbach Alpha & No of Items \\
\hline 1 & Over confidence & 0.79 & 6 \\
\hline 2 & Herding Effect & 0.87 & 7 \\
\hline 3 & Gambling Fallacy & 0.82 & 8 \\
\hline 4 & Regret Aversion & 0.75 & 6 \\
\hline 5 & Financial Decision Making & 0.85 & 6 \\
\hline
\end{tabular}

Source: Authors own estimation.

\section{Empirical results}

\subsection{Demographic Frequencies Distribution}

\subsubsection{Gender}

The sample indicated the domination of one gender (Table 2) when concerning the participants of the survey. Of the total sample size of 244 respondents $(\mathrm{N}=244), 204$ respondents were male, which represents $83.6 \%$ of the total sample size, while merely 40 respondents were female, which represents $16.4 \%$ of the total sample size. This fact can be related to the business environment, with mainly men involved in the business.

Table 2

Frequency Distribution concerning "Gender"

\begin{tabular}{lll}
\hline & Number of Responses $(\mathrm{N}=244)$ & \\
\cline { 2 - 3 } & Frequency & Percent \\
\hline Male & 204 & 83.6 \\
\hline Female & 40 & 16.4 \\
\hline Total & 244 & 100.0 \\
\hline
\end{tabular}

Source: Authors own estimation.

\subsubsection{Age}

The sample was categorized into five age groups for the variable of age i) 18-24, ii) 26-33, iii) 34-41, iv) $42-49$, v) 50 or above. 117 respondents from the sample frame indicated being between the age of 18-25 years, which represents $48 \%$ of the total sample size. 102 respondents were in the age group from 2633, comprising $41.8 \%$ of the total sample size. Twenty-four respondents were from the third category, that is between the ages of 34-41 years, representing $9.8 \%$ of the total sample. Only one respondent indicated being between $42-49$ years old $(0.4 \%)$.

Table 3

Frequency Distribution concerning "Age"

\begin{tabular}{lcc}
\hline & \multicolumn{2}{c}{ Number of Responses $(\mathrm{N}=244)$} \\
\cline { 2 - 3 } Age (years) & Frequency & Percentage \\
\hline $18-25$ & 117 & 48.0 \\
\hline $26-33$ & 102 & 41.8 \\
\hline $34-41$ & 24 & 9.8 \\
\hline $42-49$ & 1 & 0.4 \\
\hline Total & 244 & 100.0 \\
\hline
\end{tabular}

Source: Authors own estimation. 


\subsubsection{Work Experience}

The sample for this demographic variable was categorized into four groups (Table 4). The sample size was dominated by respondents having between 1-3 years' work experience (54.9\%), followed by 64 respondents who claimed to have work experience in the range of 4-6 years (26.2\%), 32 respondents with work experience of 7-9 years (13.1\%), and finally, 14 respondents indicating to have work experience of 10 years or more, which represents $5.7 \%$ of the total sample size.

Table 4

Frequency Distribution concerning "Work Experience"

\begin{tabular}{llll}
\hline & \multicolumn{3}{c}{ Number of Responses $(\mathrm{N}=244)$} \\
\cline { 2 - 4 } & 134 & Frequency & Percentage \\
\hline $1-3$ & 64 & 54.9 \\
\hline $4-6$ & 32 & 26.2 \\
\hline $7-9$ & 14 & 13.1 \\
\hline Ten or above & 244 & 5.7 \\
\hline Total & & 100.0 \\
\hline
\end{tabular}

Source: Authors own estimation.

\subsubsection{Frequency Distribution concerning "Education."}

The sample for this demographic variable was divided into five categories, high school eduction, Bachelors, Masters, MS/M. Phil and Ph.D. Only three respondents were high school eduction $(1.2 \%)$, 132 respondents $(54.1 \%)$ had a bachelor's degree, 91 respondents $(37.3 \%)$ had a master's degree and 18 respondents indicated having MS/M.Phil, - hence making for $7.4 \%$ of the total sample size.

Table 5

Frequency Distribution concerning "Education"

\begin{tabular}{|c|c|c|}
\hline & \multicolumn{2}{|c|}{ Number of Responses $(\mathrm{N}=244)$} \\
\hline & Frequency & Percentage \\
\hline $\begin{array}{l}\text { Intermediate (high school } \\
\text { eduction) }\end{array}$ & 3 & 1.2 \\
\hline Bachelors & 132 & 54.1 \\
\hline Masters & 91 & 37.3 \\
\hline MS/M.Phil. & 18 & 7.4 \\
\hline Total & 244 & 100.0 \\
\hline
\end{tabular}

Source: Authors own estimation.

\subsubsection{Descriptive Statistics}

Descriptive statistics involve the transformation of raw data into a form that would provide information to describe a set of factors in a situation. This is done by the ordering and manipulation of the raw data collected. Descriptive statistics are provided by frequencies, measures of central tendency, and dispersion (Sekaran \& Bougie, 2003). The descriptive statistics of the variables are shown in the table: the mean and standard deviation of Overconfidence Biases $(M=3.6552$, $\mathrm{SD}=0.58296)$; the mean and standard deviation of Herding Effect is $(\mathrm{M}=3.7580, \mathrm{SD}=0.49809)$; the mean and standard deviation of gambler's fallacy is $(\mathrm{M}=3.6393, \mathrm{SD}=0.46810)$; the mean and standard deviation of Real estate market prices is $(\mathrm{M}=3.3380, \mathrm{SD}=0.37809)$.

Table 6

Descriptive Statistics

\begin{tabular}{|c|c|c|c|c|c|c|}
\hline & Mean & Std. Deviation & Skewness & & Kurtosis & \\
\hline & Statistic & Statistic & Statistic & Std. Error & Statistic & Std. Error \\
\hline $\begin{array}{ll}\text { Financial Decision } \\
\text { Making }\end{array}$ & 3.3380 & 0.37809 & -0.212 & 0.146 & 0.126 & 0.290 \\
\hline
\end{tabular}




\begin{tabular}{lllllll}
\hline Herding Effect & 3.7580 & 0.49809 & -0.228 & 0.146 & 0.126 & 0.290 \\
\hline Overconfidence & 3.6552 & 0.58296 & -0.178 & 0.146 & -0.403 & 0.290 \\
\hline Regret Aversion & 3.5190 & 0.56891 & -0.134 & 0.146 & -0.242 & 0.290 \\
\hline Gambler's fallacy & 3.6393 & 0.46810 & -0.268 & 0.146 & 0.058 & 0.290 \\
\hline
\end{tabular}

Source: Authors own estimation.

\subsection{Correlation Analysis}

The researcher is interested in delineating the critical variables associated with the problem; the study is called a correlational analysis (Sekaran \& Bougie, 2003). Correlation analysis studies the joint variation of two or more variables for determining the amount of correlation between two or more variables (Wenden, 1981). The table reports the values of Pearson correlation, and the significant correlation of variables.

Table 7

Correlation Matrix

\begin{tabular}{lccccc}
\hline Pearson Correlation & $\begin{array}{c}\text { Financial } \\
\text { Decision } \\
\text { Making }\end{array}$ & $\begin{array}{c}\text { Herding } \\
\text { Effect }\end{array}$ & $\begin{array}{c}\text { Overconfidence } \\
\text { Bias }\end{array}$ & $\begin{array}{c}\text { Regret } \\
\text { Aversion }\end{array}$ & $\begin{array}{c}\text { Gambler's } \\
\text { fallacy }\end{array}$ \\
\hline $\begin{array}{l}\text { Financial Decision } \\
\text { Making }\end{array}$ & 1 & & & & \\
\hline Herding Effect & $.255^{* *}$ & 1 & & & \\
\hline Overconfidence Bias & $.138^{*}$ & $.423^{* *}$ & 1 & 1 & \\
\hline Regret Aversion & 0.031 & 0.000 & 0.009 & $.401^{* *}$ & 1 \\
\hline Gambler's fallacy & $.625^{* *}$ & $.424^{* *}$ & $.484^{* *}$ &
\end{tabular}

Source: Authors own estimation.

\subsection{Regression Analysis}

A study of functional relationships existing between two or more variables, this analysis can be termed as regression analysis. It is adopted when the researcher has one dependent variable, which is presumed to be a function of two or more independent variables. The objective of this analysis is to predict the dependent variable based on its covariance with all the concerned independent variables (Wenden, 1981).

Table 8

Regression Analysis

\begin{tabular}{llllll}
\hline & \multicolumn{2}{l}{$\begin{array}{l}\text { Unstandardized } \\
\text { Coefficients }\end{array}$} & $\begin{array}{l}\text { Standardized } \\
\text { Coefficients }\end{array}$ & \\
\cline { 2 - 6 } & $\mathrm{B}$ & Std. Error & Beta & T & P Value. \\
\hline (Constant) & 12.573 & 0.190 & & 0.838 & 0.403 \\
\hline Herding Effect & 0.068 & 0.034 & 0.012 & 2.027 & 0.044 \\
\hline Overconfidence Bias & 3.618 & 0.029 & 0.741 & 125.581 & 0.000 \\
\hline Regret Aversion & 0.025 & 0.030 & 0.005 & 2.029 & 0.045 \\
\hline Gambler's fallacy & 3.580 & 0.036 & 0.589 & 99.360 & 0.000 \\
\hline $\mathrm{R}^{2}$ & 0.891 & & & & \\
Adjusted R $\mathrm{R}^{2}$ & 0.895 & & & & .000 \\
F-static & 0.7504 & & & & \\
\hline
\end{tabular}

Dependent Variable: Financial Decision Making (Real Estate Price).

Source: Authors own estimation.

To test the model, linear regression analysis is performed on the data. The results are shown in the table. It is observed in the data presented in a table that the effect of Overconfidence Biases on real estate market prices at work is positive and significant $(\mathrm{B}=3.618, \mathrm{SE}=0.029, \mathrm{~T}=125.581$, and 
$p=0.000)$. This means that Overconfidence Biases influence the real estate market prices. Moreover, it is observed from the data presented in the table above that the effect of the Herding Effect on real estate market prices is positive and significant $(\mathrm{B}=0.068, \mathrm{SE}=0.034, \mathrm{~T}=2.027$, and $\mathrm{P}=0.044)$. This means that the Herding Effect increases real estate market prices. Furthermore, it is observed in the data presented in the table that the effect of gambler's fallacy on real estate market prices is positive and significant $(B=3.580, S E=0.036, T=99.360, P=0.000)$.

\section{Discussion and Conclusions}

The purpose of this study was to test the impact of behavioral biases or Heuristic biases on real estate prices in Pakistan based on different studies and the impact of behavioral biases on prices it was expected that the these biases would influence real estate prices in Pakistan as well. This study shows that overconfidence has a positive effect on real estate prices in Pakistan. Investors agree that the lack of financial information on real estate causes delays and hinders them when it comes to decision making. The respondents claimed to focus on the end effect of market performance, which is greatly affected by financial information on real estate markets. The value of the un-standardized regression co-efficient demonstrates a positive effect on real estate prices. Overconfidence had already been shown to have a significant effect on real estate prices in Kenya in past studies, and thus our results are in line with past findings.

The findings of the study also represented the results of herd behavior to be parallel to those of overconfidence, i.e. significant and positive effect on real estate prices in Pakistan. This bias can be avoided by many investors if they carefully analyze the market trends and price movements instead of following other investors in the market. However, our findings revealed that respondents react quickly to the decisions taken by the majority of investors to moderate the effect of decisions taken by investors caused by herd behavior. Regression analysis shows herd behavior to have a positive and significant effect on real estate prices. Gambler's fallacy also has an influence on real estate prices in Pakistan. The respondents agreed that they make decisions with high expectations, also taking past prices and many other important factors under consideration when making investment decisions. Investors moreover agreed that they normally expect higher gains on their original investment in real estate than those anticipated on other markets.

Our study has confirmed past results and our expectations. Behavioral biases have a positive and significant impact on real estate prices in Pakistan as well. Based on research analysis, the following can be concluded. Behavioral biases have a significant effect on prices, and this change may be positive or negative based on the nature of the relationship between the variables under study. Investors are prone to being affected - they will sometimes receive gains while other times, suffer immense losses; this is more likely to happen again and again if they are unaware of these biases, and may become disastrous for the investor, even leading to the impossibility of regaining one's financial position. In our study, it is observed that behavioral biases have an influence on real estate prices, and real estate investors should be guided to be careful when making investment decisions in order to avoid losses. Future studies may consider disposition effect bias and the moderating variable of investor type along with the variables of the current study, by increasing the sample size and taking advantage of the latest statistical tools.

\section{References}

Aigbovo, O., \& Ilaboya, O. J. (2019). Does Behavioural Biases Influences Individual Investment Decisions. Management Science Review, 10(1), 68-89.

Asad, H., Khan, A. A. T. I. Q. A., \& Faiz, R. (2018). Behavioral Biases across the Stock Market Investors: Evidence from Pakistan. Pakistan Economic and Social Review, 56(1), 185-209.

Atif Sattar, M., Toseef, M., \& Fahad Sattar, M. (2020). Behavioral Finance Biases in Investment Decision Making. International Journal of Accounting, Finance and Risk Management, 5(2), p.69. https://doi.org/10.11648/j.ijafrm.20200502.11

Barberis, N., \& Thaler, R. (2003). A survey of behavioral finance. Handbook of the Economics of Finance, 1, Vol. 1B. Financial markets and asset pricing, pp.1053-1128.

Babajide, A. A., \& Adetiloye, K. A. (2012). Investors' behavioural biases and the security market: An empirical study of the Nigerian security market. Accounting and Finance Research, 1(1), 219-229. https://doi.org/10.5430/afr.v1n1p219 
Brown, D. T. (2000). Liquidity and Liquidation: Evidence from Real Estate Investment Trusts. The Journal of Finance, 55, 469-485. https://doi.org/10.1111/0022-1082.00213

Bracha, A., \& Brown, D. J. (2012). Affective decision making: A theory of optimism bias. Games and Economic Behavior, 75(1), 67-80. https://doi.org/10.1016/i.geb.2011.11.004

Burtch, G. (2011). Herding behavior as a network externality. In International Conference on Information Systems 2011, ICIS 2011, 1061-1076.

Chhapra, I.U., Kashif, M., Rehan, R. \& Bai, A. (2018). An empirical investigation of investors behavioral biases on financial decision making. Asian Journal of Empirical Research, 8(3), pp.99-109. DOI: 10.18488/journal.1007/2018.7.3/1007.3.99.109

Constantinescu, M. (2010). What is the "duration" of Swiss direct real estate? Journal of Property Investment \& Finance, 28(3), 181-197. https://doi.org/10.1108/14635781011048849

Choka, D. (2014). The effect of investor sentiment on real estate investment decisions in Kenya (Doctoral dissertation).

Caparrelli, F., D'Arcangelis, A. M., \& Cassuto, A. (2004). Herding in the Italian stock market: A case of behavioral finance. Journal of Behavioral Finance, 5(4), 222-230. https://doi.org/10.1207/s15427579jpfm0504_5

De Bondt, W. F., \& Thaler, R. H. (1995). Financial decision-making in markets and firms: A behavioral perspective. Handbooks in Operations Research and Management Science, 9, 385-410. https://doi.org/10.1016/S0927-0507(05)80057-X

Daniel, K., \& Hirshleifer, D. (2015). Overconfident investors, predictable returns, and excessive trading. The Journal of Economic Perspectives, 29(4), 61-88. https://doi.org/10.1257/jep.29.4.61

Darrat, A. F., Zhong, M., \& Cheng, L. T. (2007). Intraday volume and volatility relations with and without public news. Journal of Banking \& Finance, 31(9), 2711-2729. https://doi.org/10.1016/j.jbankfin.2006.11.019

Feduzi, A., \& Runde, J. (2014). Uncovering unknown unknowns: Towards a Baconian approach to management decision-making. Organizational Behavior and Human Decision Processes, 124(2), 268283. https://doi.org/10.1016/j.obhdp.2014.04.001

Ehrlinger, J., Mitchum, A. L., \& Dweck, C. S. (2016). Understanding overconfidence: Theories of intelligence, preferential attention, and distorted self-assessment. Journal of Experimental Social Psychology, 63, 94-100. https:// doi.org/10.1016/i.jesp.2015.11.001

Filiz, I., Nahmer, T., Spiwoks, M., \& Bizer, K. (2018). Portfolio diversification: The influence of herding, status-quo bias, and the gambler's fallacy. Financial Markets and Portfolio Management, 32(2), 167205. https://doi.org/10.1007/s11408-018-0311-x

Hilton, D. (2006). Overconfidence, trading and entrepreneurship: cognitive and cultural processes in risk-taking (Vol. 280). Contributions to Economic Analysis.

Jennergren, L. P. (2011). A tutorial on the discounted cash flow model for valuation of companies. SSE/EFI Working paper series in business administration, (1998), p.1.

Kallinterakis, V., Munir, N., \& Radovic-Markovic, M. (2010). Herd behaviour, illiquidity and extreme market states: Evidence from Banja Luka. Journal of Emerging Market Finance, 9(3), 305-324. https://doi.org/10.1177/097265271000900303

Kahneman, D., \& Tversky, A. (1979). Prospect Theory: An Analysis of Decision under Risk. Econometrical, 47(2), 263-291. https://doi.org/10.2307/1914185

Kahneman, D., \& Tversky, A. (1981). The simulation heuristic (No. TR-5). Stanford Univ CA Dept of Psychology.

Kahneman, D., \& Tversky, A. (2013). Choices, values, and frames. In Handbook of the fundamentals of financial decision making: Part I (pp. 269-278). https://doi.org/10.1142/9789814417358_0016

Kempf, A., \& Ruenzi, S. (2006). Status quo bias and the number of alternatives: An empirical illustration from the mutual fund industry. Journal of Behavioral Finance, 7(4), 204-213. https://doi.org/10.1207/s15427579jpfm0704_3

Khan, D. (2020). Cognitive Driven Biases, Investment Decision Making: The Moderating Role of Financial Literacy. Investment Decision Making: The Moderating Role of Financial Literacy, January 5, 2020).

Khan, M.T.I., Tan, S.H., Chong, L.L. \& Ong, H.B. (2017). Investment characteristics, stock characteristics and portfolio diversification of finance professionals. Borsa Istanbul Review, 17(3), pp.164-177.https://doi.org/10.1016/j.bir.2017.04.001. 
Le Luong, P. \& Thi Thu Ha, D. (2011). Behavioral factors influencing individual investors' decisionmaking and performance: A survey at the Ho Chi Minh Stock Exchange.

Lopes, P.N.(2016). Emotional intelligence in organizations: Bridging research and practice. Emotion Review, 8(4), pp.316-321.https://doi.org/10.1177/1754073916650496

Malmendier, U., \& Tate, G. (2005). CEO overconfidence and corporate investment. The Journal of Finance, 60(6), 2661-2700. https://doi.org/10.1111/j.1540-6261.2005.00813.x

Madaan, G. \&Singh, S. (2019). An Analysis of Behavioral Biases in Investment DecisionMaking. International Journal of Financial Research, 10(4), pp.5567.https://doi.org/10.5430/ijfr.v10n4p55

Majewski, S. (201). November. Could the Volatility Be a Measure of Investors' Optimism? In International Conference on Computational Methods in Experimental Economics (pp. 133-142). Springer, Cham.

Mather, M., Mazar, N., Gorlick, M. A., Lighthall, N. R., Burgeno, J., Schoeke, A., \& Ariely, D. (2012). Risk preferences and aging: The "certainty effect" in older adults' decision making. Psychology and Aging, 27(4), 801-816. https://doi.org/10.1037/a0030174 PMID:23066800

Montier, J. (2009). Behavioural investing: a practitioner's guide to applying behavioral finance. John Wiley \& Sons.

Muhammad, N. M. N. (2009). Behavioural finance vs traditional finance. Adv. Manage, 2(6), 1-10.

Mushinada, V.N.C. and Veluri, V.S.S., 2018. Investors overconfidence behaviour at Bombay stock exchange. International Journal of Managerial Finance. https://doi.org/10.1108/IJMF-05-2017-0093

Ndiritu, B. G. (2015). The effect of behavioral bias and frame dependence on real estate prices in Nairobi county (Doctoral dissertation, University of Nairobi).

Njenga, E. N., \& Kagiri, A. (2018). Effect Of Behavioral Bias On Real Estate Prices In Kenya (A Case Of Real Estates In Kiambu County).

Odean, T. (1998). Are investors reluctant to realize their losses? The Journal of Finance, 53(5), 1775-1798. https:// doi.org/10.1111/0022-1082.00072

Obeng-Odoom, F. (2015). Informal real estate brokerage as a socially-embedded market for economic development in Africa. Real estate, construction and economic development in emerging market economies, 224.

Pompian, M.M. \&Wood, A.S.(2006). Behavioral finance and wealth management: How to build optimal portfolios for private clients.

Phan, T. C., Rieger, M. O., \& Wang, M. (2018). What leads to overtrading and under-diversification? Survey evidence from retail investors in an emerging market. Journal of Behavioral and Experimental Finance, 19, 39-55. https:// doi.org/10.1016/i.jbef.2018.04.001

Ritter, J. R. (2003). Behavioral finance. Pacific-Basin Finance Journal, 11(4), 429-437. https://doi.org/10.1016/S0927-538X(03)00048-9

Rabin, M. (2002). Inference by believers in the law of small numbers. The Quarterly Journal of Economics, 117(3), 775-816. https://doi.org/10.1162/003355302760193896

Rakesh, H. M. (2014). A study on individuals investors behavior in stock markets of India. International Journal of Management and Social Sciences, 2(2), 165-174.

Razek, Y. H. A. (2011). An overview of behavioral finance and revisiting the behavioral life cycle hypothesis. IUP Journal of Behavioral Finance, 8(3), 7.

Ritter, J. R. (2003). Differences between European and American IPO markets. European Financial Management, 9(4), 421-434. https:// doi.org/10.1111/1468-036X.00230

Sekaran, U., \& Bougie, R. (2003). Research Methods For Business, A Skill Building Approach, John Willey \& Sons. Inc. New York.

Shah, S. Z. A., Ahmad, M., \& Mahmood, F. (2018). Heuristic biases in investment decision-making and perceived market efficiency. Qualitative Research in Financial Markets. https://doi.org/10.1108/QRFM-04-2017-0033

Statman, M. (2009). The cultures of insider trading. Journal of Business Ethics, 89(S1), 51-58. https://doi.org/10.1007/s10551-008-9905-y

Stilwell, F. (2011). Political economy: The contest of economic ideas. OUP Catalogue.

Tan, L., Chiang, T. C., Mason, J. R., \& Nelling, E. (2008). Herding behavior in Chinese stock markets: An examination of A and B shares. Pacific-Basin Finance Journal, 16(1-2), 61-77. https://doi.org/10.1016/j.pacfin.2007.04.004 
Tversky, A. \& Kahneman, D. (1974). Judgment under uncertainty: Heuristics and biases. Science, 185(4157), 1124-1131.

Waweru, N. M., Munyoki, E., \& Uliana, E. (2008). The effects of behavioural factors in investment decision-making: A survey of institutional investors operating at the Nairobi Stock Exchange. International Journal of Business and Emerging Markets, 1(1), 24-41. https:// doi.org/10.1504/IJBEM.2008.019243

Wenden, A.L. (1981). The Processes of Self Directed Learning: A Study of Adult Language Learners. 